\title{
Turha, ärsyttävä ja arka aihe?
}

Quomalaiset naiset lienevät maailman mestareita innossaan osallistua kaikenlaiSseen aikuiskoulutukseen. Kansliapäällikkö Markku Linna luonnehti tätä hiljan aikuiskoulutuksen keskeiseksi ongelmaksi - eikä ole kauan siitä, kun opettajakuntien naisvaltaisuus todettiin uhkaksi kansakunnan tulevaisuudelle. Onko keskiluokkaisista, keski-ikäisistä, korkeasti koulutetuista naisista tullut uusi etuoikeutettu luokka koulutusyhteiskunnassamme? Heidänkö pitää epäillä tuottavan syrjäytyvää miehistä alaluokkaa, jota elinikäisen oppimisen ilosanoma ei puhuttele? Aikuiskasvatuksen tutkijatapaamisessa taas miestutkijat vähän aikaa sitten valittivat suomalaisnaisten innottomuutta feminismiin, joka - paremman puutteessa - kannattelisi kriittisen ja radikaalin tutkimuksen jatkuvuutta. Naistenko tulee kunnostaa nämä miesten käynnistämät kasvatuksen projektit?

\footnotetext{
A ikuiskasvatusta koskevat periaatteet, sanastot ja teoriat eivät perinteisesti oletunnistaneet sukupuolieroa. Vaikka kansanvalistus ja -sivistys ei erotellut kansan ikäkausia tai sukupuolia, vain miehiä kirjattiin liikkeiden ja aatteiden historiaan. Ehkä ideaalikansalaisuus oli kaukana niin todellisista miehistä kuin naisistakin, mutta miksi naiset olivat valmiita samaistumaan sen miehisyyteen? Onko kyse samasta ilmiöstä, jonka Ann-Catrin Östman on todennut tutkimuksessaan. Hänen mukaansa suomalaisen sukupuolten työkumppanuussuhde rakentuu perinteisellä tavalla siten: naisetkin arvostivat itseään työkumppanina yhteisössä arvokkaammiksi luokiteltujen miehisten töiden tekemisen, osaamisen tai tukemisen perusteella. Vai oliko kansakunnan rakentaminen sittenkin naisille yleisinhimillinen arvo ja lupaus "naisystävällisen" valtion mahdollisuudesta? Tavallaan lupaus on toteutunutkin, mutta eriyttämällä enenevästi naisten ja miesten maailmat toisistaan työssä ja muussa elämässä.
}

Aikuiskasvatuksen myöhemmissä vaiheissakaan ei andragogiikan aikuiselle, konstruktivismin itseohjautuvalle oppijalle tai asiantuntijalle ilmestynyt sukupuolta. Ei myöskään liberaalin ja kriittisen aikuispedagogiikan ohjelmien tiedostava yhteiskunnallinen osallistuja ole rämpinyt hoivahuolien ja riippuvuuksien maailmassa. Aikuiskasvatuksen tutkijoista ja tämänkin lehden kirjoittajista yhä suurempi osa on naisia, mutta sanastot, lähestymistavat tai kysymyksenasettelut eivät juuri erota heitä miehistä. Onko aikuiskasvatuksen naisistuminen siis osoitus ihannemiehisyyden universaalista hyvyydestä vai erilaisuuksien vaimentamisesta, yhä enemmän myös naisten tuella? Myös kasvatuksen ja kasvatustieteen kentällä sukupuolen ja sukupuolittamisen merkityksiä ovat muunakin kuin neutraalina taustamuuttujina kysyneet lähinnä naistutkijat naisten kannalta. Orastava miestutkimus ei aikuiskasvatukseen ole uskaltautunut. 

tin kriisiytymistä" kasvatuksen haasteena. Työväenluokan naiset näyttäisivät sopeutuneen paremmin paikkaansa keskiluokkaistuneessa ja toimihenkilöistyneessä yhteiskunnassa. Vaikka ilmaus ei suomalaiseen perinteeseen aivan sopisikaan, se haastaa kysymään myös "keskiluokkaisia maskuliniteetteja ja femininiteettejä", joita me aikuiskasvattajat ja -tutkijat itse henkilöimme ja ruumiillistamme. Sivistyneistö ja tutkijat ovat perinteisesti kohdistaneet katseensa joko alaspäin, köyhiin ja osattomiin, tai ylöspäin rikkaisiin ja valtaapitäviin, mutta oman ideologisen kodin ja sen laajentumisen kriittinen pohdinta on paljon vaikeampaa.

1 aisten kollektiivinen - etenkin maapalloinen - vähäosaisuus taloudelrustelee erityisten naisohjelmien rakentamista koulutuksessa ja tutkimuksessa. Suomalainen sukupuoli-sana kuitenkin jo viittaa ilmiön suhteisuuteen: niin naisten aseman parantaminen kuin miesongelman ratkaiseminenkin saattavat vaatia maskuliniteettien ja femininiteettien muotoutumisen tarkastelemista yhdessä, suhteessa toisiinsa. Aihe on monesta vielä turha, ärsyttävä ja arkakin, mutta sukupuolinäkökulman esiin nostaminen voi johtaa aikuiskasvatusta koskevan keskustelun ja tutkimuksen yleisempään uudistamiseen, kyseenalaistamiseen ja virkistämiseen. Kiperiä kysymyksiä riittää ja niihin vastausten etsimisessä tehtävää, niistä antavat esimerkkejä teemanumeron kirjoitukset.

Anja Heikkinen

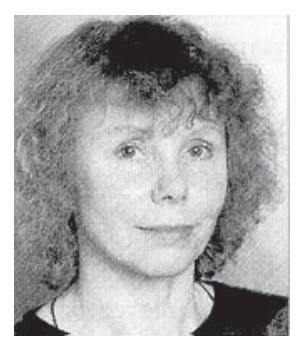

